\title{
津波の流れに対する被覆ブロックの 安定性に関する検討
}

\author{
三井 順 1 ・ 久保田真一 2 ・松本 朗 3 \\ 1正会員＼cjkstart株式会社不動テトラ 総合技術研究所（†300-0006 茨城県土浦市東中貫町2-7） \\ E-mail:jun.mitsui@fudotetra.co.jp \\ 2正会員 株式会社不動テトラ 総合技術研究所（厂 $300-0006$ 茨城県土浦市東中貫町2-7） \\ E-mail:shinichi.kubota@fudotetra.co.jp \\ 3正会員＼cjkstart株式会社不動テトラ 総合技術研究所（ \\ E-mail:akira.matsumoto@fudotetra.co.jp
}

\begin{abstract}
津波の流れに対する被覆材の安定性に関する基礎的な知見を得ることを目的として，台形マウンドでの 実験と, 堤頭部を再現した実験の2種類の水理模型実験を実施した。津波の流れによる被覆ブロックの移 動形態として, マウンドの法肩部や稜線部からの離脱と, ケーソン際の天端部からの離脱の 2 種類の形態 を確認した. 移動形態によって安定限界時のイスバッシュ定数が異なっており, 後者の移動形態に関して は抗力以外の要因により離脱が生じている可能性が示唆された。またイスバッシュ式の適用に関しては, 適切な斜面勾配のとり方や流速の測定位置を検討することが今後の課題として挙げられる．その際，イス バッシュ定数を決定するための実験時とイスバッシュ式により所要質量を算定する際との定義を整合させ ることが必要である.
\end{abstract}

Key Words : tsunami, current, armor units, stability, Isbash formula

\section{1. はじめに}

防波堤の津波対策においては，津波の流れに対してマ ウンド被覆材の安定性を確保することが必要である．流 れに対する被覆材の所要質量算定方法としては, 以下に 示すCERCによるイスバッシュの式放通常用いられてい る.

$$
M=\frac{\pi \rho_{r} U^{6}}{48 g^{3} y^{6}\left(S_{r}-1\right)^{3}(\cos \theta-\sin \theta)^{3}}
$$

ここに，M は捨石等の質量， $\rho$ は捨石等の密度，Uは流 速， $g$ は重力加速度， $y$ はイスバッシュの定数，S $r$ は捨 石等の水に対する比重， $\theta$ は斜面勾配である，イスバッ シュの定数は埋め込まれた石の場合は1.20, 露出した石 の場合は0.86とされている.

津波の流れに対する被覆材の安定性の検討事例として, 岩崎ら 2はは潜堤のマウンド被覆材にテトラポッドを用い て定常流による断面実験を行っており，イスバッシュの

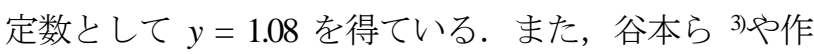
中・有川 4は釜石港湾口防波堤の開口部の潜堤を対象と した平面実験を行っており，被覆材のイスバッシュの定 数を算定している.
イスバッシュの定数は本来ブロック形状に固有の值で あるが，津波の流れに対する被覆材の安定性に関寸る検 討事例は未だ少なく，ブロック形状によらず岩崎ら 2)に よる值が設計に用いられているのが現状である. 而津波 設計の精度向上のためには，ブロック形状ごとのイスバ ッシュ定数を実験により決定していくことが必要である と考えられる．その際，イスバッシュの式における斜面 勾配のとり方や流速の測定位置など不明確な点が多く, 実験方法や整理方法によって值が大きく変化することが 想定される. また，堤頭部などの複雑な流れ場に対して のイスバッシュ式の適用性も不明である. そこで本研究 では，津波の流れに対する被覆材の安定性に関する基礎 的な知見を得ることを目的として，台形マウンドでの実 験と，堤頭部を再現した実験の 2 種類の水理模型実験を 実施した. 前者は現象を単純化した条件，後者はより現 地に近い条件という位置づけである. そして，その結果 をもとに今後の設計手法の確立に向けた議論を行う。

\section{2. 台形マウンドでの実験}

\section{(1) 実験方法}

実験には, 長さ50 m, 幅 $1.0 \mathrm{~m}$, 高さ.1.5 mの二次元水 
平面図(奥行き方向 5 倍で表示)
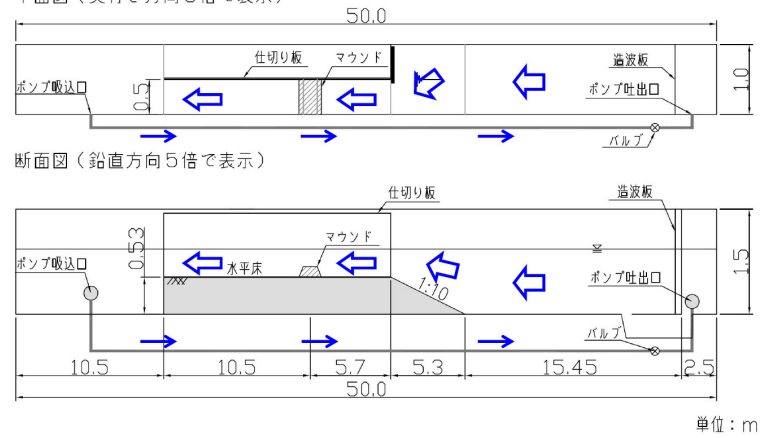

図-1 実験装置の模式図

表-1＼cjkstart被覆ブロック諸元（括弧内は現地量）

\begin{tabular}{c|c}
\hline & \\
\hline 形状図 & $46.8 \mathrm{~mm}(2.34 \mathrm{~m})$ \\
\hline 長さ $L$ & $16.8 \mathrm{~mm}(0.84 \mathrm{~m})$ \\
\hline 高さ $H$ & $34.7 \mathrm{~g}(4.34 \mathrm{t})$ \\
\hline 質量 $M$ & $14.4 \mathrm{~cm}^{3}\left(1.80 \mathrm{~m}^{3}\right)$ \\
\hline 体積 $V$ & $2.40 \mathrm{~g} / \mathrm{cm}^{3}\left(2.40 \mathrm{t}^{3}\right)$ \\
\hline 密度 $\rho$ &
\end{tabular}

槽を使用した. 水槽には渦巻きポンプが設置されており, 循環流を発生させることが可能である.

図-1に実験装置の模式図を示す. 水平なモルタル床上 にマウンドを設置し，ポンプを作動させることにより定 常状態の流れを発生させた。 十分な流速を発生させるた めに, 仕切り板により水路幅を $1 \mathrm{~m}$ から $0.5 \mathrm{~m}$ に狭めた.

模型縮尺は1/50とし，実験に関わる諸量はフルードの 相似則に従うものとした. 実験に用いた被覆ブロック模 型の諸元を表-1に示す.ブロック模型はモルタルで製作 し, 表乾状態の質量が表-1に示寸值の $\pm 3 \%$ 以内のもの を使用した. マウンド模型の断面図を図-2に示す. マウ ンドの幅は約 $1 \mathrm{~m}$ ，高さ $15 \mathrm{~cm}$ ，斜面勾配は1:2とした。

イスバッシュの定数を求めるためには, ブロックの安 定限界時のブロック近傍流速を測定する必要がある. し かし, 安定実験と近傍流速の測定は同時に行うことが困 難であったため, 安定実験と流速測定は別々に実施した。

まず安定実験方法を以下に述べる，台形マウンドでの 実験においては流速を上げていく際にポンプの流量は変 化させず，水路内の初期水深を $0.5 \sim 1.0 \mathrm{~cm}$ 刻みで段階 的に下げていくことでブロック近傍流速を上げていき， ブロックの安定限界を調べた。流量は使用したポンプの 発生可能な最大の流量（約 $7 \mathrm{~m} / \mathrm{min}$ ) である. 流速を上 げていく際にはブロックの積み直しは行わず, 継続して 次のランクの津波を作用させた．津波の作用時間は，流 れがほぼ定常となってから現地量で 15 分間（模型量で 127秒間) とした.

水路の側壁に接する各 1列のブロックは観察対象外之 し，ブロックが動かないように固定した。なお，上流

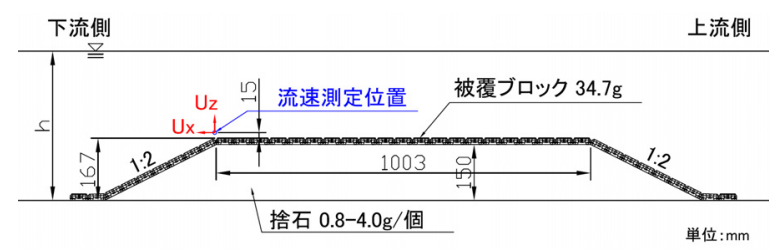

図-2 実験断面図（台形マウンド実験）
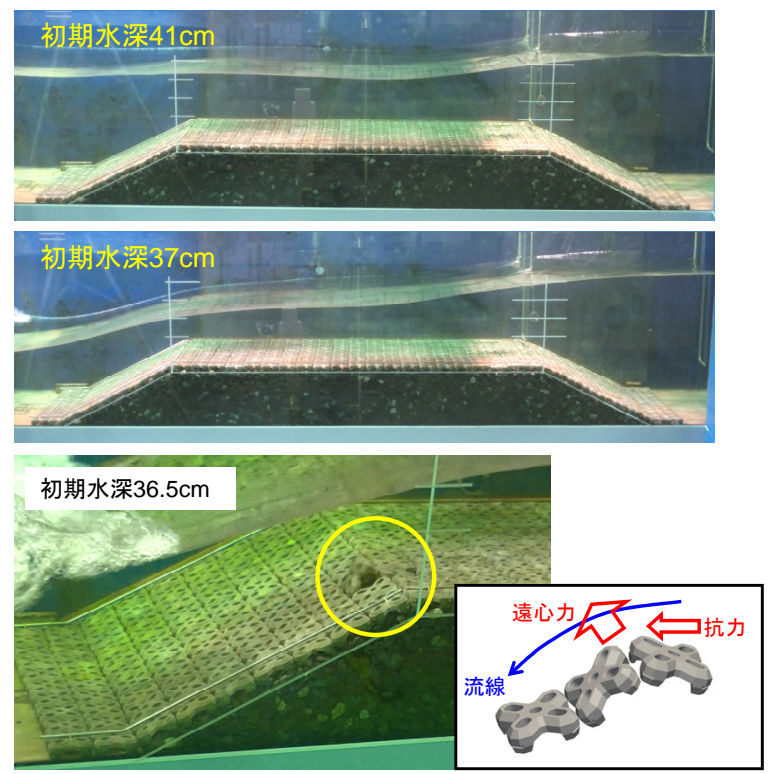

図-3＼cjkstart津波作用状況およびブロック離脱状況 （台形マウンド実験，1回目）

端・下流端の法先のブロックは固定せずにモルタル床上 に設置した. 安定実験は2回繰り返し実施した.

流速測定の際には，ブロック同士を連結した状態で安 定実験と同じ津波を発生させてブロック近傍流速を測定 した。測定位置は図-2 に示すように，下流側のマウン ド法肩位置とした。 これは安定実験においてブロックの 初期被害が発生した箇所である. 流速の測定高さは有川 ら 5)を参考にブロック天端上 $1.5 \mathrm{~cm}$ （現地量で $75 \mathrm{~cm}$ ）と した．電磁流速計を用いて流下方向および鉛直方向の 2 成分の流速 $U_{x}, U_{z}$ を $0.05 \mathrm{~s}$ のインターバルで測定した.

\section{(2) 実験結果}

\section{a) 安定実験結果}

実験 1 回目は初期水深 $41.0 \mathrm{~cm}$ から開始し, 初期水深 $36.5 \mathrm{~cm}$ の条件でブロックに被害が生じた．津波作用状 況およびブロックの離脱状況を図-3 に示す.ブロック

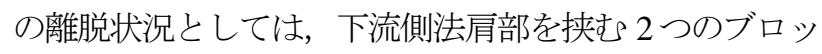
クが「くの字」になるようにして離脱し，下流側一流さ れた. その後急激に被害が拡大し，ほぼマウンド全体に わたってブロックおよび砕石が流出した. 2 回目の実験 は初期水深 $38.5 \mathrm{~cm}$ から開始した. ブロックに被害が生 じたのは 1 回目の実験と同じ津波ランクであり, ブロッ クの離脱状況も 1 回目と同様であった. マウンド天端部 の最も下流側のブロックには図-3 に示すように下流側 


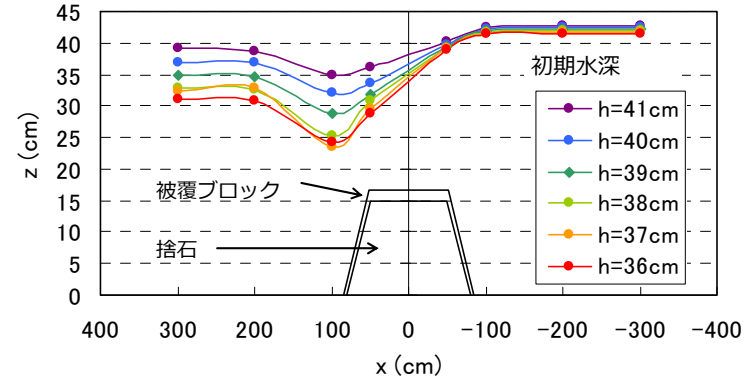

図-4 水位の空間分布

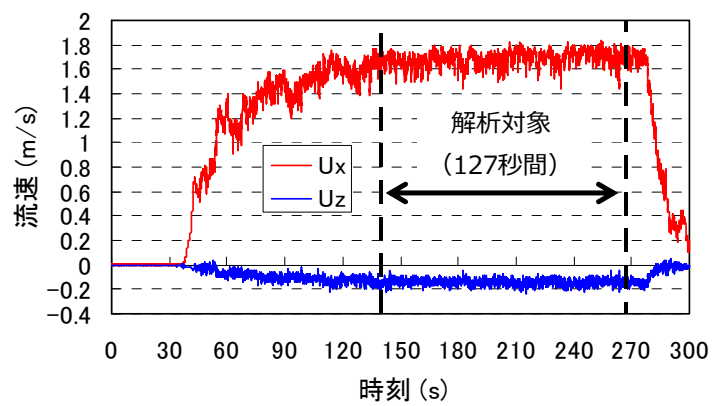

図-5 ブロック近傍流速の時系列（初期水深 37.0cm）

一滑動する方向に抗力が作用するとともに，法肩近傍の 流線が上に凸の曲率を持つことにより法肩付近の圧力が 低下し，離脱する方向の力がブロックに作用していた可 能性がある.

\section{b) 流速測定結果}

初期水深ごとの水位の空間分布を図-4 に示寸。水位 は解析対象とした 127 秒間の平均值である. 水路内の初 期水深を下げていくと，上流側の水位は概小変化せず, 下流側の水位が低下していくことがわかる．安定限界の 条件である初期水深 $37.0 \mathrm{~cm}$ のときの下流側法肩位置に おける流速の時系列を図-5 に示寸．解析対象とした 127 秒間（現地量で 15 分間）は概ね一定の流速であること が確認できる. 初期水深と水平流速の関係を図-6 に示 す．流速は解析対象とした 127 秒間の平均值である．初 期水深を下げていくことで下流側の水位が低下寸るため, 下流側の法肩位置での流速が大きくなっている．また， 別途測定した下流側法肩位置における流速の鉛直分布を 図-7 に示す．これは定常状態となった後に流速計を鈆 直方向に動かしながら測定したものであり，30 秒間の 平均值である. 本研究では暫定的にブロック天端上 1.5 $\mathrm{cm}$ (現地量で $75 \mathrm{~cm}$ ) の流速をイスバッシュ定数の算定 に用いることとしたが，図-7 からわかるように測定高 さによる流速の変化はブロック近傍では特に大きくなっ ており，イスバッシュ式で用いる流速の測定高さを明確 に定めることが重要であることがわかる.

\section{c) イスバッシュ定数の算定}

安定限界時のブロック近傍流速を用いて，被覆ブロッ クのイスバッシュ定数を算定した結果を表-2 に示す.

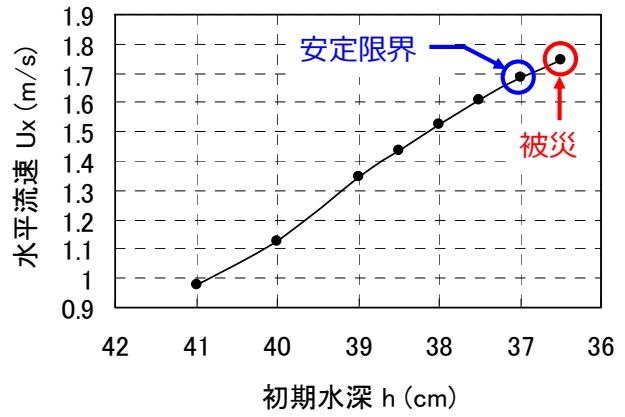

図-6 初期水深と水平流速の関係

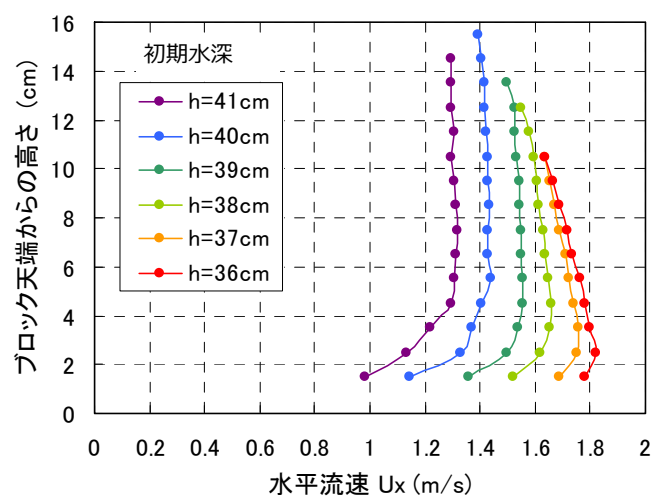

図-7 下流側法肩位置における流速の鉛直分布

表-2 イスバッシュ定数の算定結果（台形マウンド実験）

\begin{tabular}{l|c|c}
\hline & 1回目 & 2回目 \\
\hline ブロック近傍流速 $U(\mathrm{~m} / \mathrm{s})$ & 1.69 & 1.69 \\
\hline ブロック質量 $M(\mathrm{~kg})$ & \multicolumn{2}{|c}{0.0347} \\
\hline ブロックの密度 $\rho_{\mathrm{r}}\left(\mathrm{kg} / \mathrm{m}^{3}\right)$ & \multicolumn{2}{|c}{2400} \\
\hline ブロックの水に対する比重 $S_{\mathrm{r}}$ & \multicolumn{2}{|c}{2.40} \\
\hline 斜面勾配 $\theta(\mathrm{deg})$ & \multicolumn{2}{|c}{0.8} \\
\hline 重力加速度 $g\left(\mathrm{~m} / \mathrm{s}^{2}\right)$ & 1.86 & 1.86 \\
\hline イスバッシュ定数 $y$ & \multicolumn{2}{|c}{} \\
\hline
\end{tabular}

現状ではイスバッシュ式における斜面勾配のとり方が明 確ではないため暫定的ではあるが，法肩を挟む天端と法 面のブロックが同時に離脱したことから， $\theta=0$ としてて イスバッシュ定数を算定した. その結果イスバッシュ定 数として $y=1.86$ が得られた. なお $\theta=26.6^{\circ}$ (勾配 1:2) として算定すると， $\theta=0^{\circ}$ とした場合と比べてイスバッ シュ定数は約 1.5 倍の值となる.

\section{3. 堤頭部を再現した実験}

\section{(1) 実験方法}

実験装置や水路内の配置は台形マウンドでの実験と同 じであるが，本実験に先立ちインバーター盤を設置し， インバーターの周波数でポンプの流量制御を行えるよう にした．邓形堰を越流させて別途測定したインバーター 周波数と流量の関係を図-8に示す.

模型縮尺は $1 / 50$ とし，使用したブロック模型は台形断 
面での実験と同じ質量34.7 gの被覆ブロックである. 堤 体の平面図および断面図を図-9に示す。本実験はケーソ ンを回り込む津波の流れに着目して安定性を検討するも のであるため，津波が越流しないようにケーソンは十分 高く設定した．ケーソンと根固方塊の模型は木製であり， 津波の流れによって動かないように水路壁に固定した. マウンド上の被覆ブロックとガラス壁に生じる隙間は鉄 柱等で埋めて，石が抜け出ないようにした。また，上流 端・下流端の法先のブロックは固定せずにモルタル床上 に設置した． 初期水深を $30 \mathrm{~cm}, 40 \mathrm{~cm}, 50 \mathrm{~cm}$ に変えた3 ケースの実験を行った。

台形マウンドでの実験と同様に，安定実験と流速測定 実験は別々に実施した。台形マウンドでの実験では水路 内の初期水深を下げていくことでブロック近傍流速を上 げていったが，本実験では初期水深は固定してポンプの

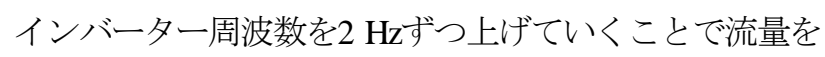
段階的に大きくし，ブロックの安定限界を調べた。流速 を上げていく際にはブロックの積み直しは行わず，継続 して次のランクの津波を作用させた．津波の作用時間は， 流れがほぼ定常となってから現地量で15分間とした。

流速測定実験では，安定実験においてブロックに離脱 が生じた1ランク手前の条件の流れを発生させてブロッ クの近傍流速を測定した. ケーソンを回り込む3次元的 な流れ場を把握するために，設置した全ての被覆ブロッ ク上で流速を測定した。 測定高さはブロック天端上 1.5

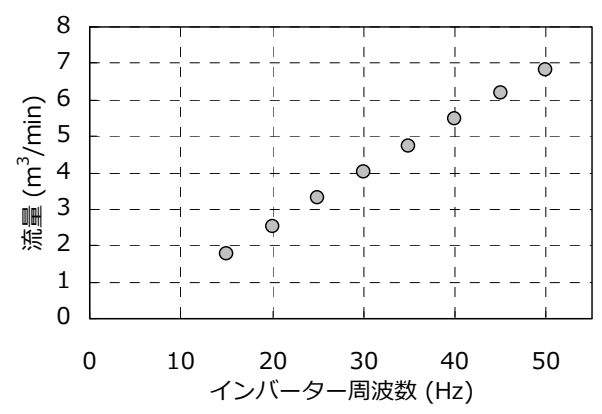

図-8 インバーター周波数と流量の関係
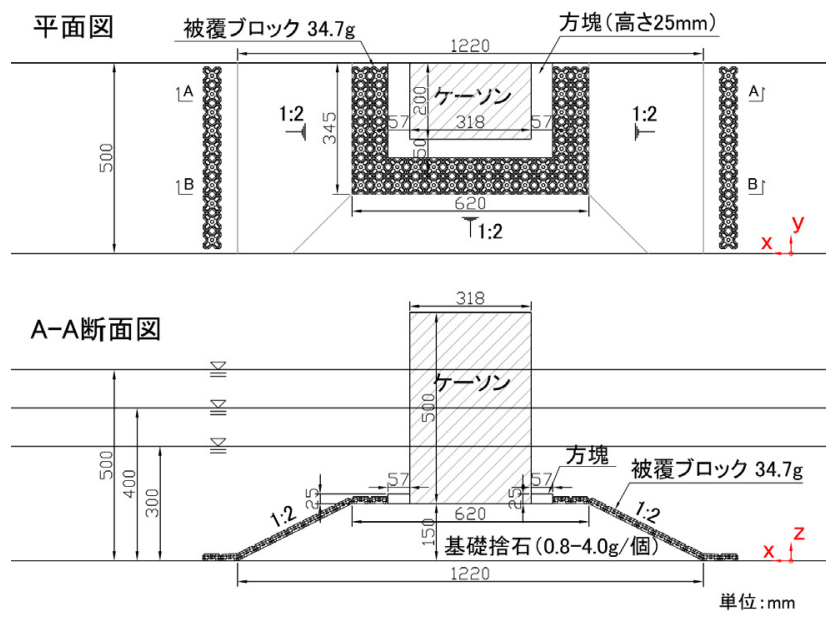

図-9＼cjkstart堤体模型の平面図と断面図（堤頭部実験） $\mathrm{cm}$ (現地量で75 cm) とし, 直軸型とL型の2種類の電磁 流速計を用いて0.01 sのインターバルでx, $y, z$ の方向の流 速（座標系は図一9を参照）を測定した。計測時間は流れ が定常状態となった後の20秒間とし，流速計の位置を動 かしていくことで各測点での流速を測定した.

\section{(2) 実験結果}

\section{a) 安定実験結果}

まず初期水深 $30 \mathrm{~cm}$ の結果を示す.インバーター周波 数 $20 \mathrm{~Hz}$ から実験を開始し，インバーター周波数 $26 \mathrm{~Hz}$ でブロックに被害が生じた.ブロックの離脱状況を図10 に示す.ブロックの離脱の形態は台形マウンドでの 実験と類似しており，下流側マウンド稜線部を挟む 2 つ のブロックが「くの字」になるようにして離脱し，下流 側へ流された。その後急激に被害が拡大し，ほぼマウン ド全体にわたってブロックおよび砕石が流出した.

初期水深 $40 \mathrm{~cm}$ のケースではインバーター周波数 30 $\mathrm{Hz}$ から実験を開始し, インバーター周波数 $42 \mathrm{~Hz}$ でブロ ックに被害が生じた。 最初にブロックの離脱が発生した 箇所や被災の状況は，初期水深 $30 \mathrm{~cm}$ のケースとほぼ同 じであった。

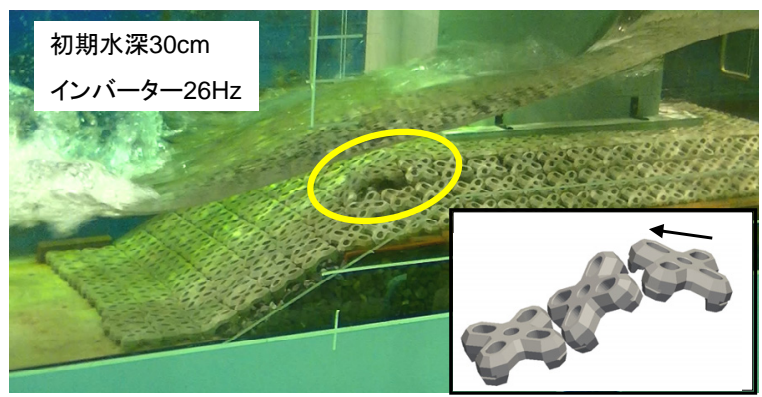

図-10 津波作用状況およびブロック離脱状況 (堤頭部実験，初期水深 $30 \mathrm{~cm}$ )
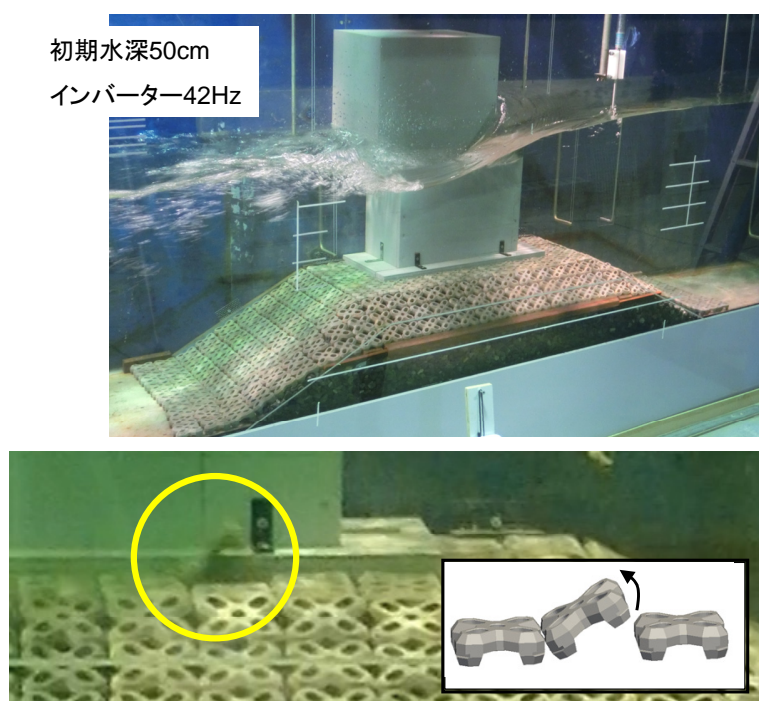

図-11 津波作用状況およびブロック離脱状況 （堤頭部実験，初期水深 $50 \mathrm{~cm}$ ) 
初期水深 $50 \mathrm{~cm}$ のケースはインバーター周波数 $36 \mathrm{~Hz}$ から実験を開始し，インバーター周波数 $44 \mathrm{~Hz}$ でマウン ド天端のケーソン際のブロック 1 個が単独で離脱した. ブロックの移動状況としては, 図-11 に示すようにブロ ックの上流側の脚が浮き上がり回転しながら離脱し，そ の後そこから石が数個抜け出した. 次の津波ランク（イ ンバーター周波数 $46 \mathrm{~Hz}$ ) では，離脱した箇所の下流側 のブロック 2 個が同じように離脱した. その後, 発生可 能な最大の流量まで実験を継続したが，石の抜け出しは 多少見られたものの，ブロックの移動やマウンドの変形 は生じなかった．このように初期水深 $50 \mathrm{~cm}$ のケースは $30 \mathrm{~cm}, 40 \mathrm{~cm}$ の場合とはブロックの初期移動の発生箇所 や被害の進行の様子などが異なっていた.

\section{b) 流速測定結果}

それぞれのケースでブロックに離脱が生じた 1 ランク 手前の条件で測定した，各被覆ブロック上の水平方向の 流速ベクトル $U_{x}, U_{y}$ の分布と, 岸沖断面（図-9 に示寸 B-B断面）における断面方向の流速ベクトル $U_{x}, U_{z}$ の分 布をそれぞれ図-12, 図-13に示寸. どのケースについて も，ケーソンを回り込むような流れが生じていることが わかる. また，初期水深 $30 \mathrm{~cm}$ と $40 \mathrm{~cm}$ のケースについ ては下流側のマウンド稜線部で流速が最大となっており, ブロックの離脱が最初に発生した箇所と対応しているこ とがわかる. 離脱発生箇所の流速の絶対值 $|U|=\left(U_{x}^{2}+U_{y}^{2}\right.$ $\left.+U_{Z}^{2}\right)^{0.5}$ は, 初期水深 $30 \mathrm{~cm}$ のケースは $1.71 \mathrm{~m} / \mathrm{s}, 40 \mathrm{~cm}$ の ケースは $1.88 \mathrm{~m} / \mathrm{s}$ であった.

一方, 初期水深 $50 \mathrm{~cm}$ のケースは他のケースと比較し

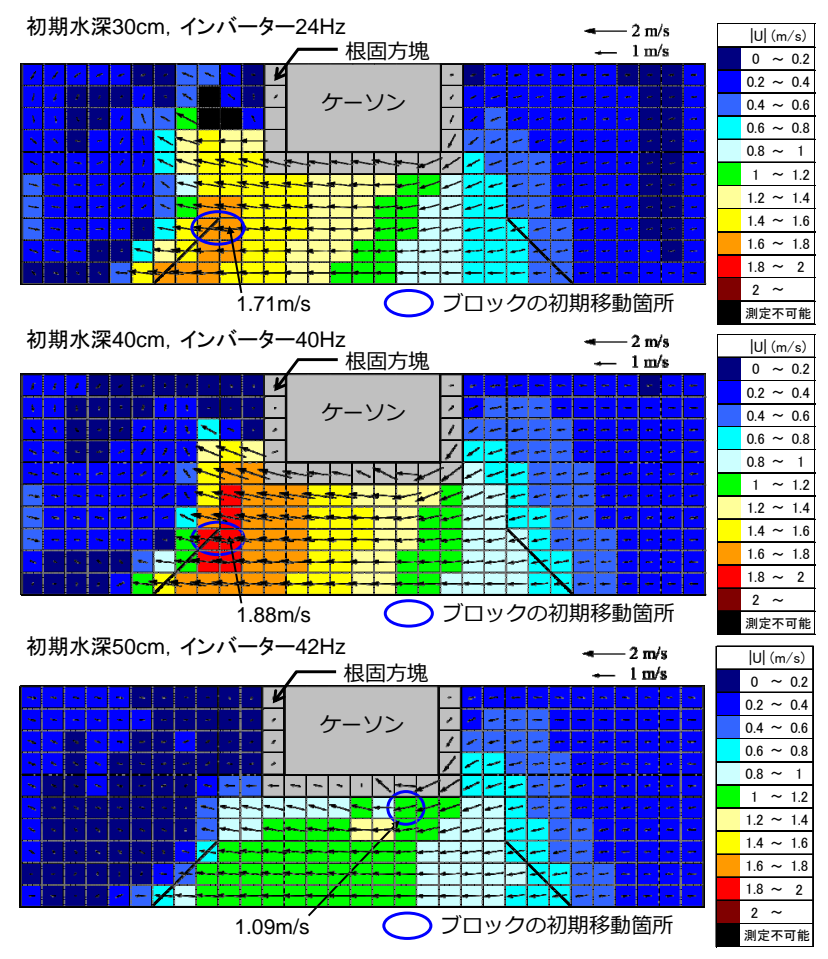

図-12 被覆ブロック上の流速分布
て全体的に流速が小さいことがわかる．ケーソンの存在 により流れが集中したと思われるケーソンの上流側の角 付近では比較的流速が大きくなっており，これはブロッ クの離脱箇所とも概ね対応しているが，離脱箇所の流速 の絶対值は $1.09 \mathrm{~m} / \mathrm{s}$ と他のケースと比較してかなり小さ い流速であった．離脱箇所付近の流速分布（図-12）を 見ると，流れがケーソンを回り込む際にケーソンの角か ら時計回りの渦が生じている様子がうかがえる. 他の初 期水深の条件にも同様の傾向が見られるが，水深が深い ほど顕著に現れているようであり，ブロックの離脱と関 連している可能性がある.

\section{c) イスバッシュ定数の算定結果}

ブロックが離脱した 1ランク手前の条件でのブロック 近傍流速を用いて，各ケースのイスバッシュ定数を算定 した. 初期水深 $30 \mathrm{~cm}$ と $40 \mathrm{~cm}$ のケースではマウンドの 稜線部（下流側の法面と手前側の法面の交線）から離脱 が生じており，やはりイスバッシュ式における斜面勾配 氺とり方が問題となる. 流れの方向は水路手前側の法 面とほぼ平行であり, 流孔の方向に対する手前側の法面 の勾配はほぼゼロであることから，暫定的に $\theta=0^{\circ}$ とし てイスバッシュ定数を算定した.

イスバッシュ定数の算定結果を表-3 に示寸. 異なる 移動形態であった初期水深 50cm のケースはイスバッシ 工定数が 1.20 と小さいが，ブロックが離脱した後の被 害は殆ど進行しない.この移動形態のメカニズムに関し ては，上で述べたようなケーソン角で発生する渦やそれ に伴う局所的な圧力低下の影響等が考えられるが，メ力

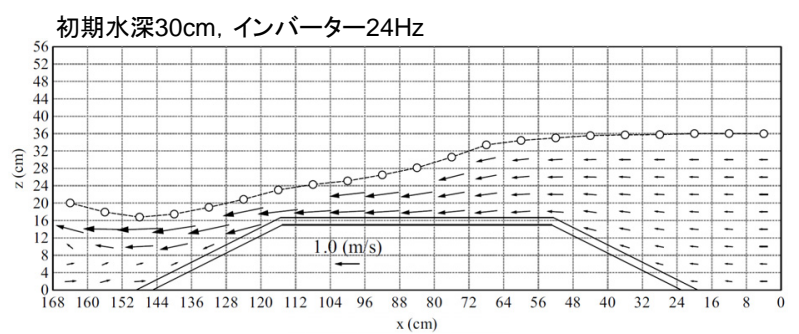

初期水深 $40 \mathrm{~cm}$, インバーター $40 \mathrm{~Hz}$

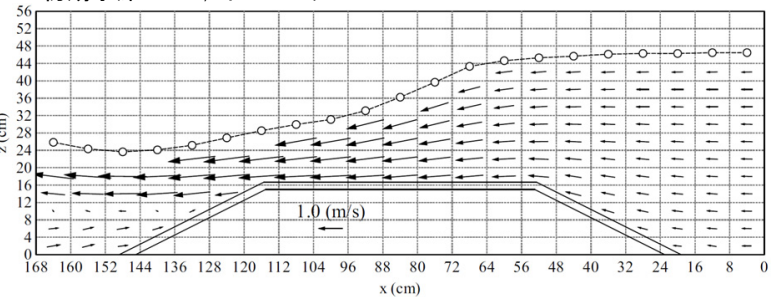

初期水深 $50 \mathrm{~cm}$, インバーター $42 \mathrm{~Hz}$

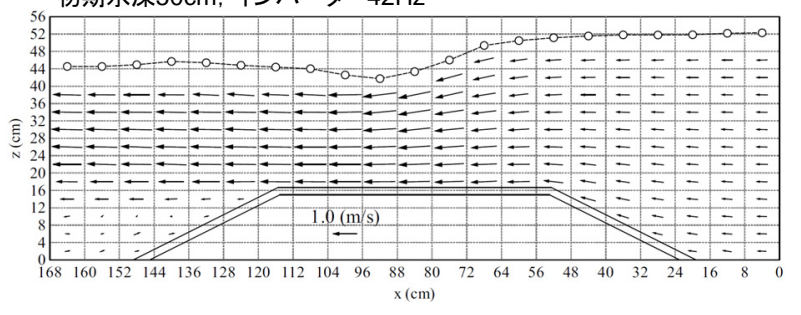

図-13 岸沖断面の流速と水位の分布 
ニズムの詳細や発生する条件などについては今後の課題 である。

一方，移動形態がほぼ同じであった初期水深 $30 \mathrm{~cm}$ と $40 \mathrm{~cm}$ の 2 ケースは, 算定されたイスバッシュ定数もそ れぞれ 1.88 と 2.06 となっており比較的近い值が得られ ていることがわかる.また，これらの值は台形マウンド での実験から得られたイスバッシュ定数 1.85 と比べて も同程度の值となった．今回の実験で得られたイスバッ シュ定数の值は既往の研究における值よりもかなり大き いが，今回用いた被覆ブロックは大きな開口部を有し揚 力が小さいわことから, 流れに対して比較的離脱しづら いためであると考えられる。

\section{4. まとめ}

本研究により得られた知見と, 設計手法の確立に向け た課題を以下に示す.

まず斜面勾配に関しては，イスバッシュ定数を決定す る実験において，今回の結果のように法肩部から離脱し た場合の斜面勾配の扱いを検討する必要がある。これに ついは，設計においてイスバッシュの式から所要質量 を算定する際の勾配のとり方と整合させることが必要で ある、また，イスバッシュ式における斜面勾配に関する 部分の式形が妥当であるかの検証はまだ十分でない. 防 波堤を越流する津波に対するブロックの安定性に関する 著者らのの検討では，CERC によるイスバッシュ式では 斜面勾配の影響が効きすぎることがわかっており，流れ に対する安定性に関しても同様である可能性がある．本 研究では勾配 1:2 の条件のみで実験を行ったが，今後， 斜面勾配を変えた実験が必要と考えられる.

流速に関しては，イスバッシュ定数を決定する際の実 験において流速の測定位置を統一するとともに，設計で 用いる際の流速とも整合させる必要がある．通常の耐津 波設計においては，シミュレーションにより算定される 流速は断面平均流速であるため, 断面平均流速からブロ ック近傍流速に換算することができれば，より精度の高 い算定が行えると考えられる。
表-3 イスバッシュ定数の算定結果（堤頭部実験）

\begin{tabular}{l|c|c|c}
\hline 初期水深 $h(\mathrm{~cm})$ & 30 & 40 & 50 \\
\hline ブロック近傍流速 $U(\mathrm{~m} / \mathrm{s})$ & 1.71 & 1.88 & 1.09 \\
\hline ブロック質量 $M(\mathrm{~kg})$ & \multicolumn{3}{|c}{0.0347} \\
\hline ブロックの密度 $\rho_{\mathrm{r}}\left(\mathrm{kg} / \mathrm{m}^{3}\right)$ & \multicolumn{3}{|c}{2400} \\
\hline ブロックの水に対する比重 $S_{\mathrm{r}}$ & \multicolumn{3}{|c}{2.40} \\
\hline 斜面勾配 $\theta(\mathrm{deg})$ & \multicolumn{3}{|c}{0} \\
\hline 重力加速度 $g\left(\mathrm{~m} / \mathrm{s}^{2}\right)$ & 1.88 & 2.06 & 1.20 \\
\hline イスバッシュ定数 $y$ &
\end{tabular}

堤頭部実験の水深が深い条件で見られた，ケーソン際 からのブロックの離脱に関しては，そのメカニズムやこ の移動形態が発生する条件などを明らかにすることも今 後の課題である.

\section{参考文献}

1) Coastal Engineering Research Center : Shore Protection Manual, U.S.Army Corps of Engrs., U.S.Govt. Printing Office, Vol. II, pp.7_213-7_216, 1977.

2) 岩崎敏夫, 真野明, 中村武弘, 堀越伸幸 : 潜堤のマ ウンド材およびプレパックド堤に作用する定常流流 体力に関寸る実験的研究, 海岸工学講演会論文集, Vol.31, pp.527-531, 1984.

3) 谷本勝利, 木村克俊, 宮崎啓司: 津波防波堤開口部 潜堤の安定性に関する実験的研究, 港湾技術研究所報 告, Vol.27, No.4, pp.93-121, 1988.

4) 作中淳一郎, 有川太郎：防波堤開口部の耐津波安定 性についての実験ならびに数值計算, 港湾空港技術研 究所資料, No.1274, 26p, 2013.

5) 有川太郎, 佐藤昌治, 下迫健一郎, 富田孝史, 廉慶 善, 丹羽竜也：津波越流時における混成堤の被災入 カニズムと腹付工の効果, 港湾空港技術研究所資料, No.1269, 37p, 2013.

6) 三井順, 松本朗, 半沢稔 : イスバッシュ式の導出過 程と防波堤を越流寸る津波一の適用性, 土木学会論文 集 B2（海岸工学）, Vol.71, No.2, pp.I_1063-I_1068, 2015.

7) 浜口正志, 久保田真一, 松本朗, 半沢稔, 山本方 人：大きな開口部を有する新しい被覆ブロックの開 発と人工リーフへの適用, 海岸工学論文集, Vol.54, pp.961-965, 2007.

(2017.3.15 受付)

\section{STABILITY OF ARMOR UNITS AGAINST TSUNAMI-INDUCED CURRENT}

\section{Jun MITSUI, Shin-ichi KUBOTA and Akira MATSUMOTO}

Two kinds of hydraulic model experiments with trapezoidal mound and breakwater head were conducted to obtain fundamental knowledge on the stability of the armor units against the tsunami-induced current. Two failure modes of the armor units such as the damage originated from the ridgeline of the mound on the downstream side and the damage at the top of the mound near the caisson edge were observed. It was suggested that the Isbash's constant at the stability limit varies depending on the failure mode and the latter failure mode may be caused by factors other than drag force. Regarding the application of the Isbash formula, strict definition of the slope angle and measurement position of the flow velocity should be investigated in the future. 